\title{
Krom III klorür tuzuna maruz kalan mayalara C vitamini katılarak mayaların antioksidan enzimlerine etkisinin araştırılması
}

\author{
The research of the effects on antioxidant enzymes of yeasts exposed to chromium III \\ chloride salt by adding vitamin $C$
}

\author{
Ebru ÇÖTELI: ${ }^{* 1, a}$, Fikret KARATAŞ⿻ి, b \\ ${ }^{1}$ Ahi Evran Üniversitesi, Sağlık Hizmetleri Meslek Yüksekokulu, Tıbbi Hizmetler ve Teknikler Bölümü, Kırşehir \\ ${ }^{2}$ Fırat Üniversitesi, Fen Fakültesi, Kimya Bölümü, Elazığ
}

• Geliş tarihi / Received: 03.04.2021 • Düzeltilerek geliş tarihi / Received in revised form: 06.06.2021 • Kabul tarihi / Accepted: 05.07.2021

\section{$\ddot{O} z$}

Son zamanlarda biyokimyasal, biyoteknolojik ve toksikolojik çalışmalarda mayalar oldukça sık kullanılmaktadır. Bu çalışmada, maya (Saccharomyces cerevisiae) mikroorganizması iki farklı dozda (10 ve $40 \mu \mathrm{g} / \mathrm{mL}) \mathrm{krom} \mathrm{III} \mathrm{klorür}$ $(\mathrm{CrCl} 3.6 \mathrm{H} 2 \mathrm{O})$ tuzuna 12, 24 ve 36 saat boyunca maruz bırakılmıştır. Krom tuzuna maruz bırakılan maya örneklerine 10 , 15 ve $20 \mu \mathrm{g} / \mathrm{mL}$ miktarlarında $\mathrm{C}$ vitamini eklenmiştir. Maya ve krom etkileşiminin mikroorganizmadaki bazı biyokimyasal parametrelere etkileri incelenmiştir. Öncelikle maya örneklerinin 12, 24 ve 36. saatteki canlılık oranları tespit edilmiştir. Ayrıca glutatyon peroksidaz (GSH-Px), Glutatyon redüktaz (GSH-Rd) ve Süperoksit dismutaz (SOD) antioksidan enzim aktivite miktarları ile total protein miktarları spektrofotometre ile ölçülerek belirlenmiştir. Çalışma sonucunda, maya örneklerinde artan krom dozu ve süreye bağlı olarak hücre sayıları ve protein miktarlarında azalmalar, artan C vitamini dozu ve süresine bağlı olarak da hücre sayıları ve protein miktarında artışların olduğu gözlemlenmiştir. Artan krom dozuna bağlı olarak maya örneklerinin GSH-Px, GSH-Rd ve SOD enzim aktivite miktarlarında artışların olduğu tespit edilmiştir. Kontrol ve diğer gruplar karşılaştırıldığında, kromun antioksidan enzim aktivite miktarlarını artırdığ 1 belirlenmiştir. Fakat besi ortamına eklenen farklı konsantrasyonlardaki $\mathrm{C}$ vitamininin, enzim aktivite miktarlarını azalttığı tespit edilmiştir. Sonuç olarak; kromun maya mikroorganizmasında serbest radikal oluşumunu artırdığı, eklenen $\mathrm{C}$ vitaminin ise antioksidan özelliğinden dolayı serbest radikal oluşumunu azalttığı sonucuna varılmıştır.

Anahtar kelimeler: CrCl3, GSH-Px, GSH-Rd, Saccharomyces cerevisiae, SOD

\begin{abstract}
Recently, yeast are used frequently in biochemical, biotechnological and toxicological studies. In this study, yeast (Saccharomyces cerevisiae) microorganism was exposed to chromium III chloride (CrCl3.6H2O) salt in two different doses (10 and $40 \mu \mathrm{g} / \mathrm{mL}$ ) for 12, 24 and 36 hours. 10, 15 and $20 \mu \mathrm{g} / \mathrm{mL}$ of vitamin $C$ was added to the yeast samples exposed to chromium salt. The effect of yeast and chromium interaction on some biochemical parameters in microorganism were investigated. Firstly, the survival rates of yeast samples at 12, 24 and 36 hours were determined. In addition, the amount of antioxidant enzyme activity of Glutathione peroxidase (GSH-Px), Glutathione reductase (GSH$R d)$ and Superoxide dismutase (SOD) and amounts of total protein were measured by spectrophotometer. It was observed that the number microorganism and amounts of protein decreased depending on increasing chromium dose and time in yeast samples, on the other hand, with the introduction of vitamin $C$, increase the number of microorganism along with amount of protein. Depending on the increasing chromium dose, the activity enzyme GSH-Px, GSH-Rd and SOD of yeast samples were found to be increased. When the control and other groups were compared, it was observed that chromium increased the amounts of antioxidant enzyme activity. However, it has been obtained that different concentrations vitamin $C$ added to the nutrient medium reduces the amounts of enzyme activity. As a result; it was concluded that while chromium increases the formation of free radicals in yeast microorganism, vitamin $C$, reduces the formation of free radicals due to its antioxidant properties.
\end{abstract}

Keywords: $\mathrm{CrCl3}$, GSH-Px, GSH-Rd, Saccharomyces cerevisiae, SOD

\footnotetext{
*a Ebru ÇÖTELİ; e.coteli@ahievran.edu.tr, Tel:+9(0386)2802224, orcid.org/0000-0002-9473-0914

${ }^{\mathrm{b}}$ orcid.org/0000-0002-0884-027X
} 


\section{Giriş}

Mayalar mantarlar âleminde yer almakta olup yaklaşık 1500 türünün olduğu bildirilmektedir (Barnett vd., 2000; Boekhout vd., 2003). Mayaların hücre yapılarının büyük oranda proteinler, polisakkaritler, lipitler, nükleik asitlerden ve inorganik maddelerden oluştuğu bildirilmektedir. Maya hücre zarı genellikle protein, lipit ve fosfat yapıdadır (Walker, 2000; Öcal, 2008; Öztürk, 2003). En iyi tanınan maya ekmek veya bira mayas1 olarak adlandirilan Saccharomyces cerevisiae' dir (Barnett, 1992). Gıda, içecek, özellikle şarap ve biyoyakıt üretim endüstrileri $S$. cerevisiae' nın kullanıldığ 1 alanlardır (Maria vd., 2020). Mayalar en fazla alkol üretimi, ekmek yapımında, turşuların yapımında, vitaminler, gliserol, lipidlerin ve proteinlerin üretiminde kullanılmaktadır (Jakobsen ve Norvhus, 1996; Hierro vd., 2004). Ayrıca gıda, kimya, ilaç ve zirai alanlarda da kullanılmaktadır (Hierro vd., 2004; Kahvecioğlu vd., 2004). S. cerevisiae' nın zengin bir folat kaynağı olarak kullanıldığı bildirilmiştir (Patring vd., 2005). Son zamanlarda S. cerevisiae ve $S$. boulardii mayaları insan ve hayvanlarda probiyotik olarak kullanılmıştır (Blanguet vd., 2001; Saegusa vd., 2004). Günümüzde mayalardan tıp alanında da yararlanılmaktadır. Özellikle mikrobiyoloji, moleküler genetik gibi birçok ana bilim dalında kullanılan organizmalar arasındadır. Ayrıca Clostridium difficile bakterisinin yol açtığ kalın bağırsak iltihabı olan kolit hastalığının tedavisinde $S$. cerevisiae' nin probiyotik olarak katk1 sağladığı bildirilmiştir (Yağmur, 2006). Mikroorganizmaların kullanılarak zararlı maddeleri temizleme işlemi çalışmalarında da mayalar kullanılmaktadır. Özellikle toksik ağır metal giderimi bunlardan birisidir (Zouboulis ve Katsoyiannis, 2004).

Günümüzde biyoteknolojik çalışmalarda mikroorganizmalar kullanılmaktadır. Özellikle maya $S$. cerevisiae' nın metal biyosorpsiyon çalışmalarında yaygın olarak kullanıldığ bilinmektedir. Ancak günümüze kadar yapılan çalışmalar, ağır metallerin maya antioksidan enzim sistemleri üzerindeki toksik etkilerini tam olarak açıklayamamıştır. $\mathrm{Bu}$ çalışma ile maya mikroorganizmasının gelişme ortamına değişik konsantrasyonlarda ilave edilen krom metalinin toksik etkisi ve bu toksik etkinin tolere edilmesinde $\mathrm{C}$ vitamininin rolünün araştırılması amaçlanmıştır. $\mathrm{Bu}$ amaçla maya $S$. cerevisiae örneklerinin hücre sayıları, total protein miktarları ve antioksidan enzimleri (glutatyon peroksidaz, glutatyon redüktaz, ve süperoksit dismutaz) gibi biyokimyasal parametrelerinin etkilenme dereceleri araştırılmıştır.

\section{Materyal ve metot}

\subsection{Biyokütlenin üretimi}

$\operatorname{Krom}\left(\mathrm{Cr}^{+3}\right)$ ' un toksik etkisini araştırmak üzere maya $S$. cerevisiae kullanılmıştır. S. cerevisiae mikroorganizması Pakmaya A.Ş.' den temin edilmiştir. Mayaların geliştirilmesinde Malt Extract Broth (Malt extract 17.0 g/L+ Mycological peptone $3.0 \mathrm{~g} / \mathrm{L}, \quad \mathrm{pH}: 5.4 \pm 0.2)$ siv1 besiyeri, mayaların ekim ve sayım işlemi için Malt Extract Agar (Malt extract $30.0 \mathrm{~g} / \mathrm{L}+$ Mycological peptone $5.0 \mathrm{~g} / \mathrm{L}+$ Agar No. $215.0 \mathrm{~g} / \mathrm{L}, \mathrm{pH}: 5.4 \pm 0.2)$ tercih edilmiştir. Besiyeri bileşimindeki maddeler distile suda çözündükten sonra otoklavda $121{ }^{\circ} \mathrm{C}^{\prime}$ de 15 dk süreyle steril edilmiştir. Çalışma süresince $S$. cerevisiae mikroorganizmasını içeren kuru maya örneği $+4{ }^{\circ} \mathrm{C}$ ' de saklanmıştır. Bütün kültürler $30^{\circ} \mathrm{C}$ ' de çalkalamalı etüvde (Gerhardt-Laboshake) 150 rpm' de inkübe edilmiştir (Korhan vd., 2012). Maya örneğinden $200 \mathrm{mg}$ tartılarak $10 \mathrm{~mL}$ Malt Extract Broth içeren tüpe ekim yapılmıştır. $30^{\circ} \mathrm{C}$ ' de 24 saat bekletilerek ön zenginleştirme işlemine tabi tutulmuştur. Zenginleştirilmiş maya örneğinden $1 \mathrm{~mL}$ alınarak $100 \mathrm{~mL}$ MEB içeren erlene aşılama yapılmış ve etüvde $30^{\circ} \mathrm{C}$ 'de 12 saat inkübasyona bırakılmıştır (Çabuk vd., 2007).

\section{2. Çalışma prosedürlerinin belirlenmesi}

\subsection{Deneyde kullanılan çözeltilerin hazırlanması}

- $\mathrm{Cr}^{+3}$ çözeltisinin hazırlanması: $\mathrm{CrCI}_{3} \cdot 6 \mathrm{H}_{2} \mathrm{O}$ (Merck) tuzundan $200 \mu \mathrm{g} / \mathrm{mL}$ stok $\mathrm{Cr}^{+3}$ çözeltisi hazırlanmıştır.

- Cvitamini çözeltisinin hazırlanması: C vitamini standardindan (Merck) $200 \mu \mathrm{g} / \mathrm{mL}$ stok C vitamini çözeltisi hazırlanmıştır.

- Lizozom enziminin hazırlanışl: 46400 Unite/mg Lizozom enzim standartından (Sigma) $20 \mathrm{mg}$ tartılmış pH' 17.38 olarak hazırlanan fosfat tamponundan $1.5 \mathrm{~mL}$ eklenerek enzimin iyice çözünmesi sağlanmıştır. Maya mikroorganizmasının parçalanmasında bu enzim kullanılmıştır.

\subsubsection{Metal-mikroorganizma etkileşiminde uygun $p H^{\prime}$ in belirlenmesi}

Metal-mikroorganizma biyosorpsiyon prosesinde $\mathrm{pH}$ en önemli faktördür. Yapılan literatür 
çalışmalarında pH değeri düşük çözeltilerde, ortamda bulunan fazla miktardaki protonlar ile metal iyonları yarışmaktadır. Böylece hücre-metal etkileşimi de azalmaktadır. Ancak ortamın pH değeri arttıkça metal iyonları daha fazla bağlanmaktadır. Ortam $\mathrm{pH}$ değerinin giderek artmasiyla ortamdaki $\mathrm{OH}^{-}$iyon konsantrasyonu da artacağından dolayı metal iyonlarının çöktüğü bildirilmiştir (Çabuk vd., 2007). Literatürde $S$. cerevisiae mayasının optimum çoğalma $\mathrm{pH}$ değerinin 3 ile 7 arasında olduğu belirlenmiştir (Bailey ve Ollis, 1986). Çalışmamızdaki uygun $\mathrm{pH}$ değerini belirlemek için; beş erlene maya kültürümüzden aynı miktarda alınarak, stok 10 ppm $\mathrm{Cr}^{+3}$ çözeltisinden aynı miktarlarda kültür örneklerine eklenmiştir. Örneklerin pH'ları 3, 4, 5, 6, 7 olacak şekilde $1 \mathrm{M} \mathrm{HCl}$ ve $1 \mathrm{M} \mathrm{NaOH}$ çözeltileri ile ayarlanmıştır. Örnekler $30{ }^{\circ} \mathrm{C}$ 'deki çalkalamalı etüvde 12,24 ve 36 . saat boyunca bekletilmiştir. $\mathrm{Bu}$ saatlerdeki kültürlerin canlılık oranları $(\mathrm{cfu} / \mathrm{mL})$ belirlenmiştir.

\subsubsection{Metal-mikroorganizma etkileşiminde uygun $\mathrm{Cr}+3$ dozlarmin belirlenmesi (LD50)}

Stok krom (III) çözeltisi $\mathrm{CrCI}_{3} \cdot 6 \mathrm{H}_{2} 0$ (Alfa Aesar) tuzundan hazırlanmıştır. S. cerevisiae' da kromun toksik etkisini araştırmak için; aynı miktar maya örneklerine 10, 20, 30, 40 ve 50 ppm stok $\mathrm{Cr}^{+3}$ çözeltilerinden aynı miktarda eklenmiştir. Bütün örneklerin $\mathrm{pH}^{\prime} \quad 1 \quad 4.0^{\prime} \mathrm{e}$ ayarlanarak $30^{\circ} \mathrm{C}$ 'deki çalkalamalı etüve bırakılmıştır. Başlangıç kültür numunesi ile değişik konsantrasyonlarda $\mathrm{Cr}^{+3}$ eklenen numunelerin 12, 24 ve 36. saatteki canlılık oranlarının (cfu/mL) nasıl değiştiği araştırılmıştır.

\subsubsection{Metal-mikroorganizma etkileşiminde uygulanacak $C$ vitamini dozlarının belirlenmesi}

200 ppm C vitamini stok çözeltisi C vitamini standardından (Merck) hazırlanmıştır. Çalışmamızda 10 ve $40 \mu \mathrm{g} / \mathrm{mL}$ krom $(\mathrm{Cr}+3)$ dozuna maruz birakılan maya örneklerimizin bazılarına 10,15 ve $20 \mu \mathrm{g} / \mathrm{mL}$ konsantrasyonlarda $\mathrm{C}$ vitamini eklenmiştir.

\subsubsection{Deney düzeneğinin hazırlanması}

Saf olarak üretilen maya örnekleri dokuz gruba ayrılmıştır.

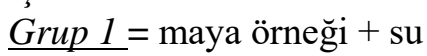

$\underline{\text { Grup 2 }}=$ maya örneği $+10 \mu \mathrm{g} / \mathrm{mL}$ krom III

klorür tuzu+su,

Grup 3 = maya örneği $+10 \mu \mathrm{g} / \mathrm{mL}$ krom III

klorür tuzu $+10 \mu \mathrm{g} / \mathrm{mL}$ C vitamini + su,

Grup 4 = maya örneği $+10 \mu \mathrm{g} / \mathrm{mL}$ krom III

klorür tuzu $+15 \mu \mathrm{g} / \mathrm{mL} \mathrm{C}$ vitamini+su,
Grup 5 = maya örneği $+10 \mu \mathrm{g} / \mathrm{mL}$ krom III klorür tuzu $+20 \mu \mathrm{g} / \mathrm{mLC}$ vitamini+su, $\underline{\text { Grup } 6}=$ maya örneği $+40 \mu \mathrm{g} / \mathrm{mL}$ krom III klorür tuzu + su,

$$
\text { Grup } 7=\text { maya örneği }+40 \mu \mathrm{g} / \mathrm{mL} \text { krom III }
$$

klorür tuzu $+10 \mu \mathrm{g} / \mathrm{mL} \mathrm{C}$ vitamini+su,

Grup $8=$ maya örneği $+40 \mu \mathrm{g} / \mathrm{mL}$ krom III klorür tuzu $+15 \mu \mathrm{g} / \mathrm{mL} \mathrm{C}$ vitamini+su,

Grup 9 = maya örneği $+40 \mu \mathrm{g} / \mathrm{mL}$ krom III klorür tuzu $+20 \mu \mathrm{g} / \mathrm{mL} \mathrm{C}$ vitamini+su

katılarak numuneler hazırlanmıştır. Toplam 120 $\mathrm{mL}$ örnek hazırlamak için; $10 \mu \mathrm{g} / \mathrm{mL} \quad \mathrm{Cr}^{+3}$ uygulanacak gruplara $(6 \mathrm{~mL}), 40 \mu \mathrm{g} / \mathrm{mL} \mathrm{Cr}^{+3}$ uygulanacak gruplara $(24 \mathrm{~mL})$ stok $\mathrm{Cr}^{+3}$ çözeltisinden eklenmiştir. Ayrıca $10 \mu \mathrm{g} / \mathrm{mL} \mathrm{C}$ vitamini uygulanacak gruplara $(6 \mathrm{~mL}), 15 \mu \mathrm{g} / \mathrm{mL}$ $\mathrm{C}$ vitamini için $(9 \mathrm{~mL}), 20 \mu \mathrm{g} / \mathrm{mL} \mathrm{C}$ vitamini için $(12 \mathrm{~mL})$ stok $\mathrm{C}$ vitamini çözeltisinden ilave edilmiştir. Bütün numuneler $\mathrm{pH}=4$ ' e ayarlanmıştır.

\subsubsection{Ham özüt hazırlanması}

Sıv1 besi ortamındaki hücrelerden ham özüt hazırlanmıştır (Jakubowsk1 ve Bartosz, 2000). Kontrol grubu ve $\mathrm{Cr}^{+3}$ uygulanmış deney grubundaki hücreler, 4500 rpm' de 20 dakika santrifüj edilerek çöktürülmüştür. Hücre çökeltisi steril saf su ile 2 kez yıkanmıştır. Daha sonra pH' 1 7.38 olan fosfat tamponuyla sulandırılmış Lizozom enziminden hücre çökeltisine birkaç damla eklenerek $5 \mathrm{dk}$ vortekslenmiştir. $1.5 \mathrm{~mL}$ deiyonize su ile süspanse edilerek her bir örnek üzerine asit ile yıkanmış $1.0 \mathrm{~g}$ cam boncuk $(0.25-0.30 \mathrm{~mm}$ çapında) ile mekanik parçalama işlemi yapılmıştır. Santrifüjlenen örneklerin üst sıvılarından 1'er mL alınarak numune tüplerine aktarılmıştır. Elde edilen ham özütler deneylerde kullanılmak üzere $20{ }^{\circ} \mathrm{C}^{\prime}$ da saklanmıştır.

\subsubsection{Ham özütteki total protein derişiminin tayini}

Total protein derişimi tayin metodu; proteinlerin alkali bakır sülfat ilavesiyle, fosfotungstik asit ile mavi renkli kompleks oluşturması esasına dayanmaktadır. Oluşan bu renkli bileşiğin spektrofotometrede $750 \mathrm{~nm}$ dalga boyunda absorbansı ölçülerek kantitatif olarak protein miktarı belirlenmiştir (Lowry vd., 1951). Standart olarak sığır serum albumin (Sigma-Aldrich) kullanılmıştır. 
2.2.8. Glutatyon peroksidaz (GSH-Px) analiz yöntemi

Glutatyon peroksidaz enzimi (GSH-Px) $\mathrm{H}_{2} \mathrm{O}_{2}$ varlığında indirgenmiş glutayonun (GSH) yükseltgenmiş glutatyona (GSSG) yükseltgenmesini kataliz etmektedir. $\mathrm{H}_{2} \mathrm{O}_{2}$ ' in bulunduğu ortamda GSH-P ${ }_{x}^{\prime}$ 'in oluşturduğu GSSG, GSH-Rd ve NADPH yardımiyla tekrar GSH' a indirgenmektedir. GSH-P $\mathrm{P}_{\mathrm{x}}$ aktivitesi NADPH' in $\mathrm{NADP}^{+}$, ye yükseltgenmesi sirasindaki absorbans farkının $340 \mathrm{~nm}$ ' de okunmasıyla ölçülmektedir (Paglia ve Valetine, 1967).

\subsubsection{Glutatyon redüktaz (GSH-Rd) analiz yöntemi}

Glutatyon redüktaz GSSG' nin NADPH tarafından GSH' a indirgenmesini katalize etmektedir. Enzim aktivitesi, tepkime sirasinda yükseltgenen NADPH' in $37{ }^{\circ} \mathrm{C}$ de $340 \mathrm{~nm}$ dalga boyundaki absorbans fark1 ile belirlenmektedir (Beutler, 1984).

\subsubsection{Süperoksit dismutaz (SOD) aktivitesinin tayini}

SOD, oksidatif enerji üretimi sırasında oluşan toksik süperoksit radikallerinin $\left(\mathrm{O}_{2}{ }^{-}\right)$hidrojen peroksit ve moleküler oksijene dismutasyonunu hızlandırır. Bu yöntem, ksantin ve ksantin oksidaz (XOD) kullanılarak oluşturulan süperoksit radikallerinin, nitro blue tetrazolium (N.B.T) ile meydana getirdiği mavi renkli formazan boyasının $560 \mathrm{~nm}$ dalga boyunda verdiği optik dansititenin (OD) okunması esasına dayanmaktadır (Sun vd., 1988).

\subsubsection{1. İstatistiksel değerlendirme}

$\mathrm{Bu}$ çalışmada incelenen her bir grup için tekrar sayıs1 $(\mathrm{n})=3$ olacak şekilde analiz edilmiştir. Çalışmadaki sonuçlar ortalama \pm standart sapma olarak verilmiştir. Deneysel sonuçlar SPSS 17.0 istatistiksel bilgisayar programı ile hesaplanmıştır. Sonuçların değerlendirilmesinde One-Sample T testi kullanılmıştır. Anlamlılık düzeyi $\mathrm{p}<0.05$ olarak belirlenmiştir.

\section{Bulgular}

Başta başlangıç kültürü olmak üzere pH' 1 3-7 civarında ayarlanmış $S$. cerevisiae örneklerinin 12 , 24. ve 36. saatteki hücre sayıları $(\mathrm{cfu} / \mathrm{mL})$ incelenmiştir. Sonuçlar Şekil 1'de gösterilmiştir.

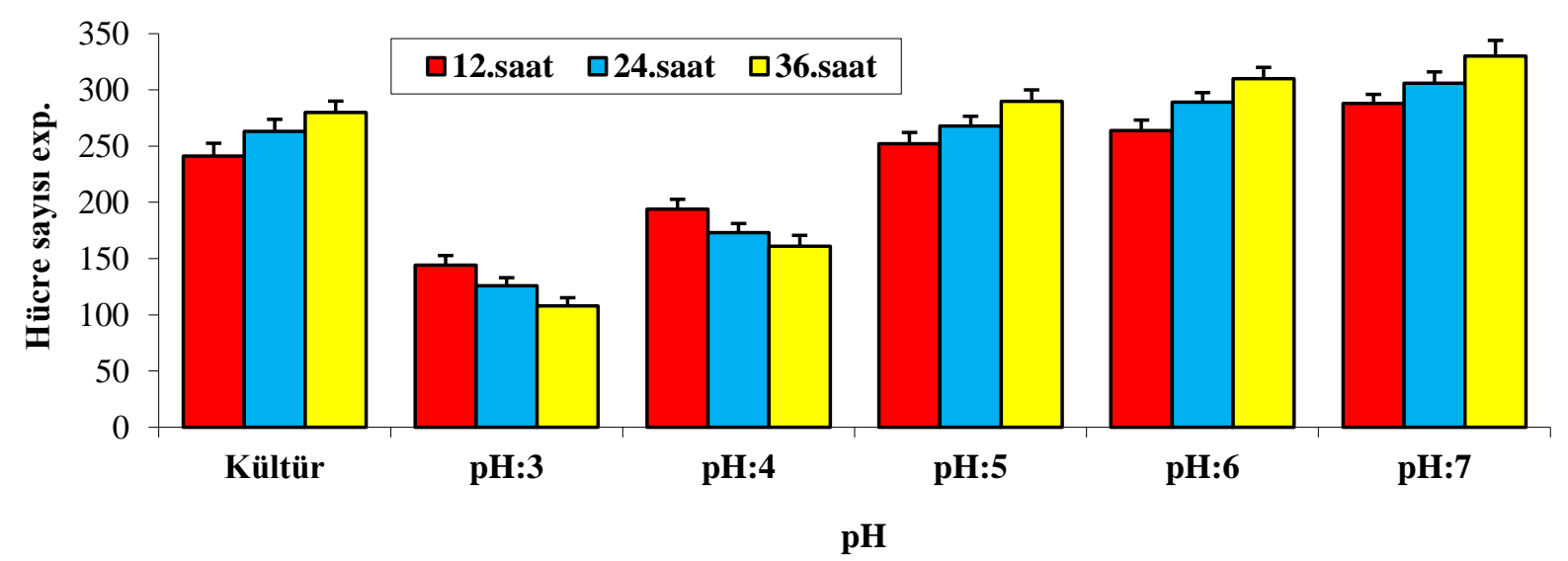

Şekil 1. S. cerevisiae ile krom etkileşiminde uygun pH' in belirlenmesi (Grafikteki hücre sayıları $10^{6}$ ile çarpılmalıdır).

Metal-mikroorganizma etkileşiminde diğer bir faktör de uygun (LD50) krom (III) dozlarının belirlenmesidir. $\mathrm{Bu}$ amaçla $10-50 \mu \mathrm{g} / \mathrm{mL}$ konsantrasyonlardaki krom çözeltileri ile maya mikroorganizmasının $\mathrm{pH}$ 4' teki toksik etkileşimi incelenmiştir. Sonuçlar Şekil 2' de gösterilmektedir. 


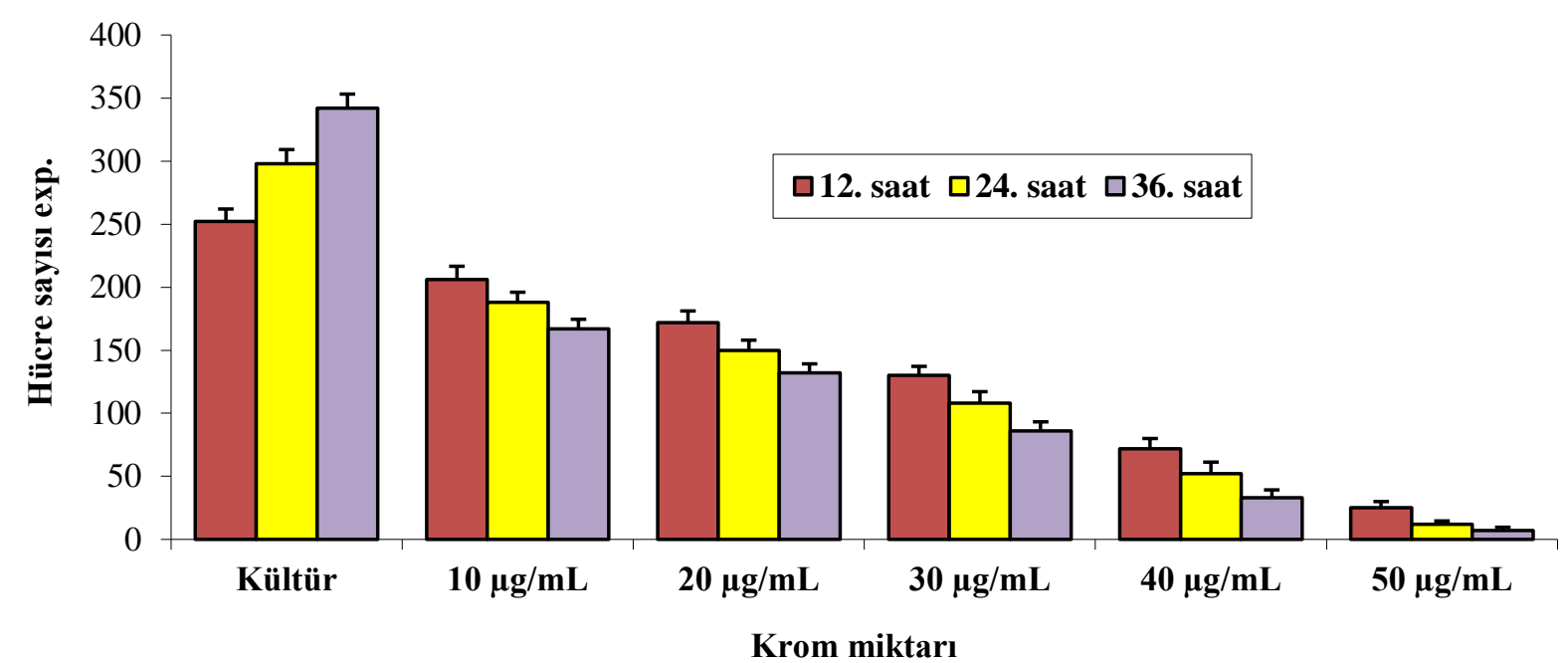

Şekil 2. S. cerevisiae' ya uygulanacak uygun krom dozlarının belirlenmesi (Grafikteki hücre sayıları $10^{6}$ ile çarpılmalıdır).

Dokuz farklı gruba ayrılmış maya örneklerinin 12, 24 ve 36. saatlerdeki hücre sayıları Şekil 3' de gösterilmektedir.

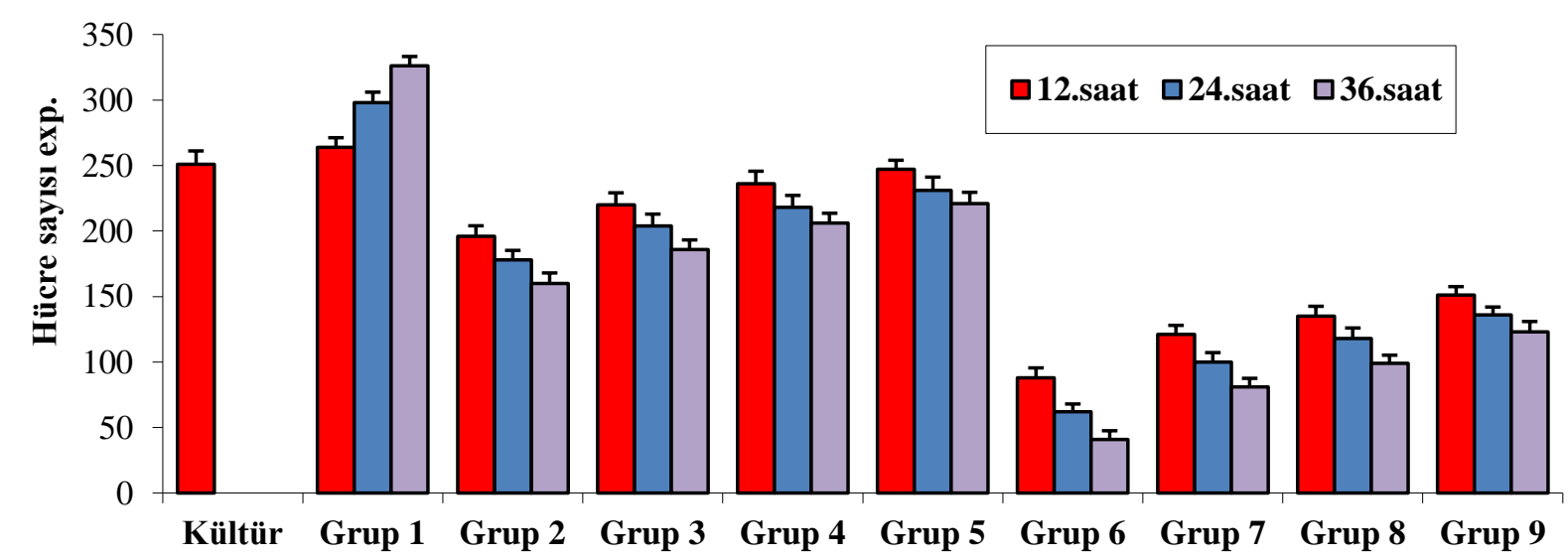

Şekil 3. Antioksidan enzimler ile total protein analizlerinin incelendiği kültürlerdeki hücre sayıları $(\mathrm{cfu} / \mathrm{mL})$ (Grafikteki hücre sayıları 106 ile çarpılmalıdır).

Dokuz farklı gruba ayrılmış maya kültürlerinin total protein miktarlarının analizleri yapılmış ve sonuçlar Şekil 4' de gösterilmiştir.

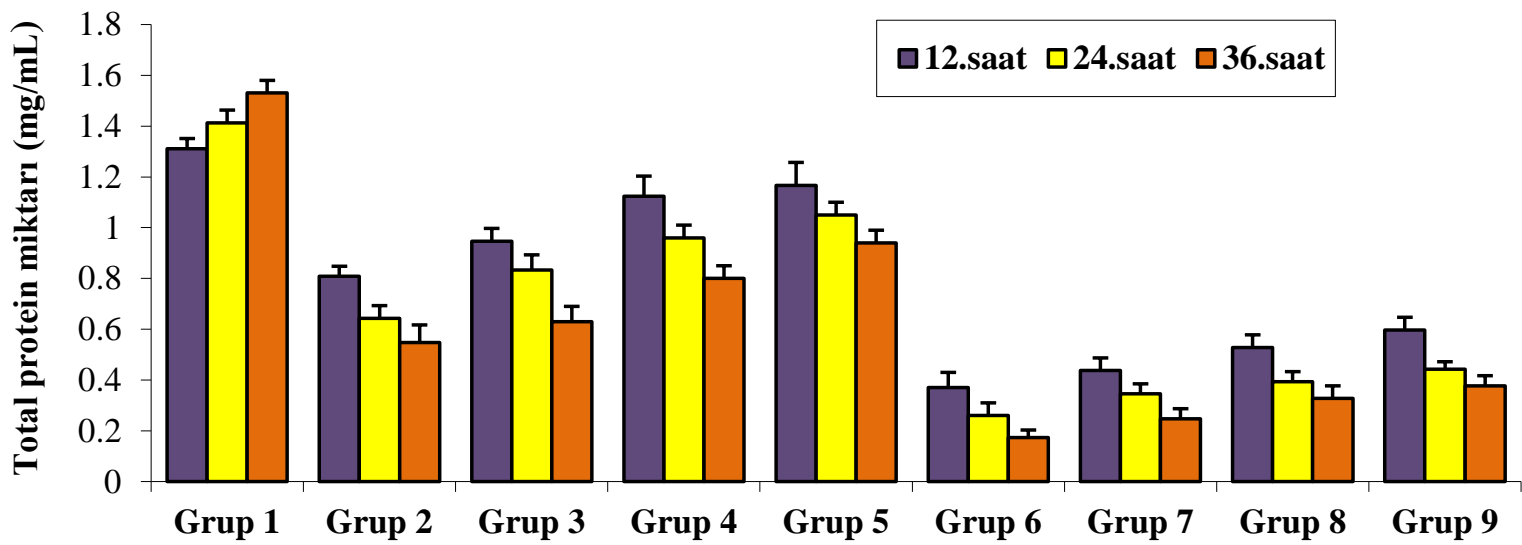

Şekil 4. Örneklerin 12, 24 ve 36. saatteki total protein miktarları 
İki farklı dozda krom uygulanan S. cerevisiae örneklerine üç farklı dozda C vitamini çözeltilerinin katılmasıyla, mayaların GSH-Px enzim aktivite miktarları Şekil 5' de gösterilmiştir.

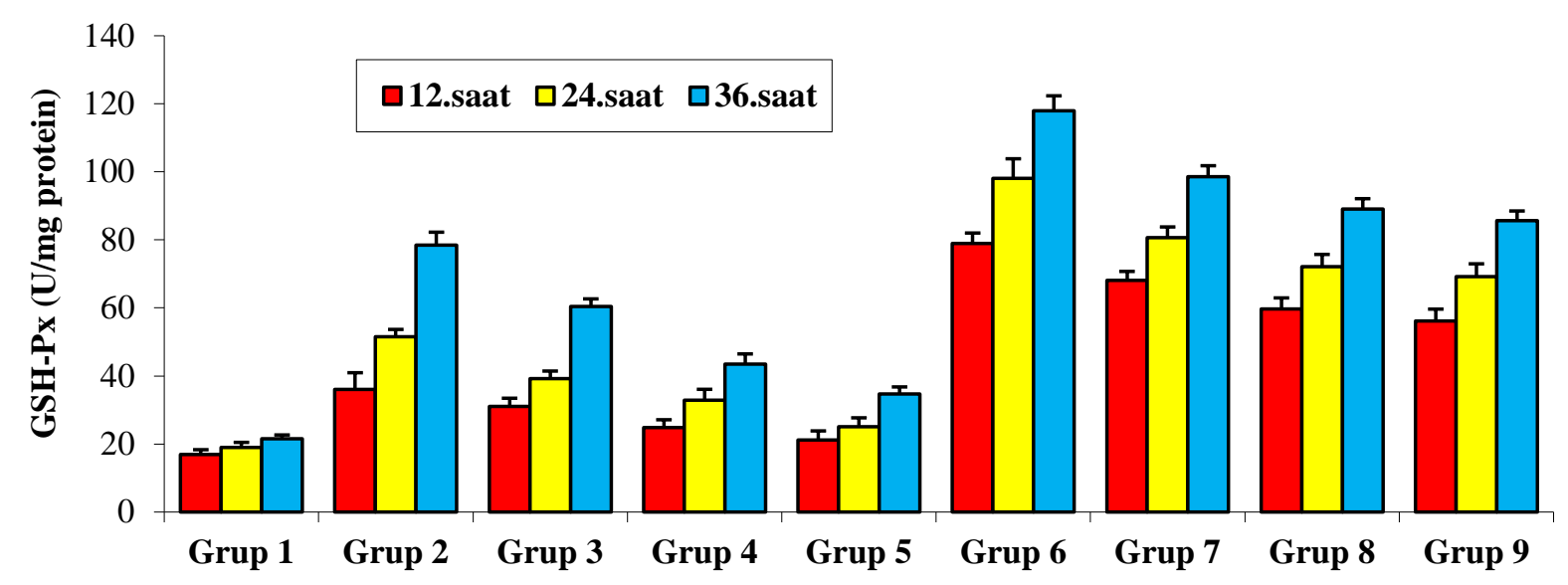

Şekil 5. Örneklerin 12, 24 ve 36. saatteki GSH-Px enzimi aktivite değerleri

Maya örneklerindeki GSH-Rd enzim aktivite miktarları Şekil 6' da gösterilmiştir.

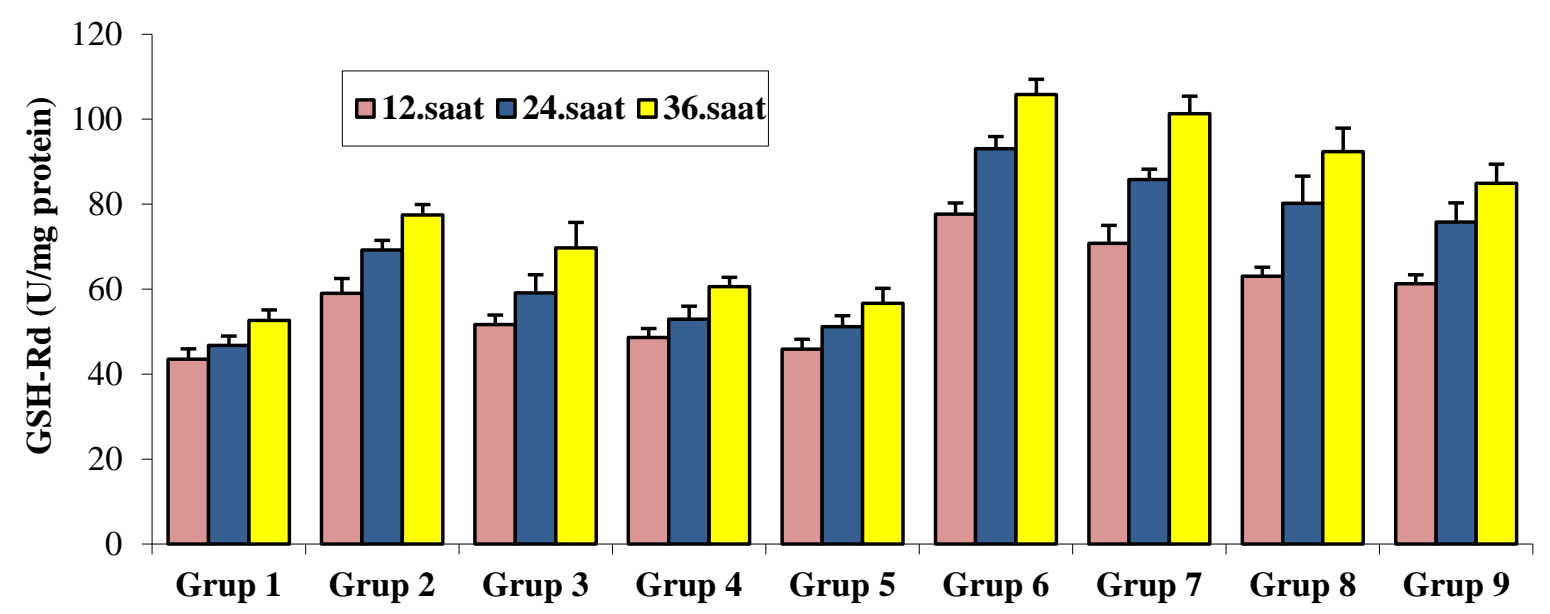

Şekil 6. Örneklerin 12, 24 ve 36. saatteki GSH-Rd enzimi aktivite değerleri

Maya örneklerinin SOD enzim aktivite miktarları da Şekil 7' de gösterilmiş̧ir.

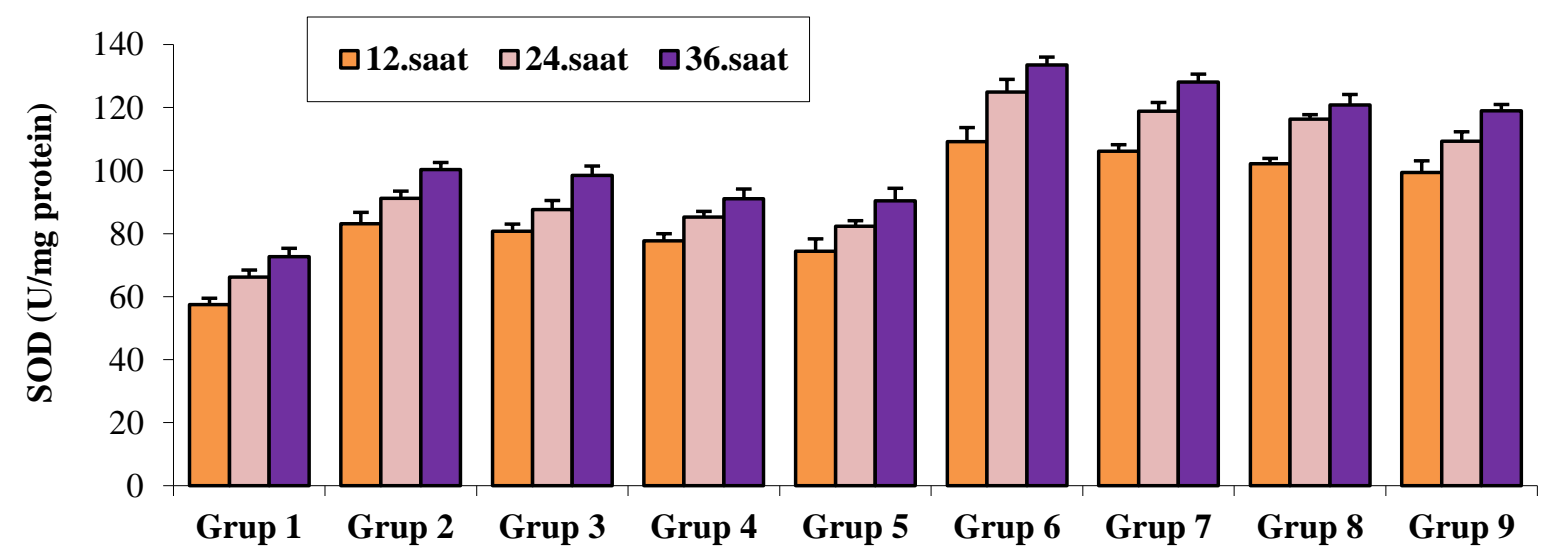

Şekil 7. Örneklerin 12, 24 ve 36. saatteki SOD enzimi aktivite değerleri 


\section{Tartışma ve sonuçlar}

Krom canlılar için gerekli eser elementlerden biri olup, fazla miktarlarda alındığında toksik olabilir (Piotrowska vd., 2008; Yang ve Chen, 2007). Kromdan etkilenen diğer bir canlı grubu mikroorganizmalardır. Oksidatif stresin zararlı etkilerini ortadan kaldırmak amacıyla oksidasyonantioksidasyon mekanizmalarını aydınlatma ve çözümler üretmeye yönelik pek çok araştırma yürütülmektedir. Özellikle başta insan olmak üzere, çeşitli canlı sistemlerinde bu mekanizmalar çok önemlidir. Maya hücreleri ile memeli hücreleri büyük oranda benzerdirler (Costa ve MoradasFerreira, 2001). Bu sebeple oksidatif stresin yol açtığ yaşlanma (Droge, 2003), apoptosis (Mandavıllı vd., 2002) ve çeşitli hastalıkları (Davıes vd., 1999), aydınlatma çalışmalarında önemlidir. Maya mikroorganizmasının stresinin; metabolizma sirasındaki kimyasal stres, üreme ortamında bulunan bileşiklerin etkileri veya mayalar tarafindan üretilen toksik metabolitlerden kaynaklandığı bildirilmektedir (Walker, 1998).

$\mathrm{Bu}$ çalışmada maya mikroorganizmasının üstel fazındaki çoğalması esnasında alınan kültürler kullanılmıştır. Canlı hücre sayısının maksimum seviyede olduğu bu evrede, krom-maya etkileşiminin araştırılması amaçlanmıştır. $S$. cerevisiae ile krom (III) toksik etkileşimin $\mathrm{pH}$ 5, 6 ve 7' de olmadığ, pH 3' de ise etkileşimin fazla derecede olduğu belirlenmiştir. $\mathrm{Bu}$ çalışmada biyokimyasal parametrelerin ölçülebilmesi için; krom metali ile maya mikroorganizmasının $\mathrm{pH}$ 4' teki toksik etkileşiminin incelenmesine karar verilmiştir. Metal-mikroorganizma etkileşiminde diğer bir faktör de ise uygun krom (III) dozlarının tespit edilmesidir. $50 \mu \mathrm{g} / \mathrm{mL}$ konsantrasyondaki kromun lethal doz olduğu gözlenmiştir. Bu sebeple çalışmada 10 ve $40 \mu \mathrm{g} / \mathrm{mL}$ olmak üzere iki farklı krom dozlarının kullanılmasına karar verilmiştir. Bu çalışmada, mikroorganizma $S$. cerevisiae' nın çoğalma ortamlarına $10 \mathrm{ve} 40 \mu \mathrm{g} / \mathrm{mL}$ gibi farklı iki krom dozu ile 10,15 ve $20 \mu \mathrm{g} / \mathrm{mL}$ olmak üzere üç farklı dozda C vitamini eklenerek pH 4' te çalışma prosedürü hazırlanılarak (Şekil 1 ve 2), çalışmadaki biyokimyasal parametreler araştırılmıştır.

Dokuz farklı gruba ayrılmıs maya örneklerinin 12, 24 ve 36. saatlerdeki hücre sayıları incelendiğinde, kontrol grubuna göre, kromun iki farklı dozunun (10 ve $40 \mu \mathrm{g} / \mathrm{mL}$ ) uygulandığı maya örneklerinin hücre sayılarında azalmalar $(\mathrm{p}<0.005)$ gözlenmiştir. Fakat ortama farklı dozlarda C vitamini eklenmesiyle doza bağlı olarak hücre sayısının da arttığı $(\mathrm{p}<0.005)$ belirlenmiştir. Ayrıca kontrol grubunda zamana bağlı olarak maya hücre sayısında artış $(p<0.005)$ gözlenmiş iken, diğer gruplarda zamana bağlı olarak azalmaların $(\mathrm{p}<0.05)$ olduğu belirlenmiştir (Şekil 3). $\mathrm{H}_{2} \mathrm{O}_{2}$ ile stres oluşturulmuş Schizosaccharomyces pombe mayasında yapılan araştırmada $S$. pombe hücrelerinde canlılık oranlarının, $\mathrm{H}_{2} \mathrm{O}_{2}$ derişimi ile ters orantılı olarak değiştiği rapor edilmiştir (Pekmez, 2004). Yine $\mathrm{H}_{2} \mathrm{O}_{2}$ ile stres oluşturulmuş $S$. pombe kültürlerinde bazı guruplara $\mathrm{E}$ vitamini analoğu olan Trolox verilmiş, trolox verilen kültürlerin canlı hücre sayılarında artışların olduğu bildirilmiştir. Trolox'un $\mathrm{H}_{2} \mathrm{O}_{2}$ stresini önlediği belirtilmiştir (Hamad, 2007). Bulgularımızın literatürle uyumlu olduğu görülmüştür.

Kültürlerin total protein miktarları karşılaştırıldığında; kontrol grubunda zamana bağlı olarak protein miktarlarında artış $(p<0.005)$ gözlenirken, diğer gruplarda zamana bağlı olarak azalmalar $(\mathrm{p}<0.05)$ saptanmıştır. Ayrıca kromun her iki dozunda ortama katılan $\mathrm{C}$ vitamini miktarına bağlı olarak protein miktarlarında da artışların olduğu $(\mathrm{p}<0.05)$ belirlenmiştir (Şekil 4). Yapılan bir çalışmada, S. cerevisiae'de oksidatif stresin spesifik olarak protein hasarına neden olduğu bildirilmiştir (Cabiscol vd., 2000). Diğer bir maya türü olan Schizosaccharomyce pombe'de $\mathrm{H}_{2} \mathrm{O}_{2}$ ile stres oluşturulmuş gruplar ile kontrol grubunun total protein değerleri karşılaştırılmış ve stres oluşturulan grupların total protein değerlerinin kontrol grubuna göre azaldığ1 saptanmıştır (Pekmez, 2004). Ayrıca Schizosaccharomyces pombe'de yapılan diğer bir çalışmada, $\mathrm{H}_{2} \mathrm{O}_{2}$ ile stres oluşturulmuş grupların bazılarına Trolox eklenmiş ve total protein değerleri karşılaştırılmıştır. Trolox verilen gruplarda total protein değerlerinin kontrol grubuna göre daha az düştüğü bildirilmiştir (Hamad, 2007). Mikroorganizma hücre sayısının arttığı kültürlerde, protein miktarının fazla olduğu rapor edilmiştir (Jianlong vd., 2004). Bu literatürlerle bulgularımızın uyum içinde olduğu belirlenmiştir.

Antioksidanlar hücrelere zarar veren serbest radikalleri ve reaktif oksijen türlerinin neden oldukları hasarı hücre içi ve hücre dışı savunma ile etkisiz hale getirirler. Hücre içi savunma glutatyon peroksidaz, glutatyon redüktaz ve süperoksit dismutaz vb. enzimler tarafindan sağlanır (Heves, 2008). Antioksidan enzimlerin başında GSH-Px gelir. Hidrojen peroksidin yüksek konsantrasyonlarının ve büyük moleküllü lipit hidroperoksitlerinin indirgenmesinde görev yapar (Szaleczky vd., 1999). Bu çalışmada kontrol grubunda zamana bağlı olarak GSH-Px enzim 
aktivite miktarlarında artışların olduğu $(\mathrm{p}<0.005)$ gözlenirken, diğer grupların hepsinde de zamana bağlı olarak enzim aktivite miktarlarında artışların olduğu tespit edilmiştir. Ancak bu artışların kontrol grubundan daha fazla olduğu $(\mathrm{p}<0.05)$ belirlenmiştir. Krom dozunun artışına bağlı olarak gruplarda GSH-Px enzim aktivite miktarlarında artışlar $(p<0.05)$ belirlenirken, artan $C$ vitamini dozuna karşılık enzim aktivite miktarlarında düşüşlerin $(\mathrm{p}<0.05)$ olduğu görülmüştür (Şekil 5). S. cerevisiae' da $\mathrm{CCl}_{4}$ ' ün yol açtığ 1 hücre hasarına Pistacia vera L.' nın koruyucu etkileri üzerine bir çalışma yapılmıştır. Çalışmada $\mathrm{CCl}_{4}$ ' ün uygulandığı gruptaki GSH-Px enzim miktarının, kontrol grubu enzim miktarından düşük olduğu, Pistacia vera $\mathrm{L}$. verilen gruplarda bu düşüşlerin daha az olduğu bildirilmiştir (Gokce, 2021). Bu çalışmada krom stresine maruz bırakılan $S$. cerevisiae' nin GSH-Px enzim aktivite miktarlarında artışlar gözlenmiştir. S. cerevisiae mikroorganizmasının farklı stres koşullarda, farklı antioksidan cevaplar verdiği sonucuna varılmıştır.

GSH-Rd enzimi, GSH-Px enzimi ile birlikte glutatyon redoks döngüsünde hidroperoksitlerin uzaklaştııılmasını sağlamaktadır (Sorg, 2004). Kontrol grubunda zamana bağlı olarak GSH-Rd enzim aktivite miktarlarında artışlar $(p<0.005)$ gözlenirken, diğer grupların tümünde zamana bağlı olarak enzim aktivite miktarlarında artışların olduğu $\quad(p<0.05)$ tespit edilmiştir. Kontrol grubunun dışındaki gruplarda artışların daha fazla olduğu belirlenmiştir. Kromun doz artışına bağlı olarak, gruplardaki GSH-Rd enzim aktivite miktarlarında artmalar $(\mathrm{p}<0.005)$ olurken, C vitamini doz artışına bağlı olarak GSH-Rd enzim aktivite miktarlarında azalmaların $(\mathrm{p}<0.005)$ olduğu belirlenmiştir (Şekil 6). Akvaryum sularına 1 ve $10 \mathrm{mg} / \mathrm{L}$ dozunda $\mathrm{Cr}$ (III) ilave edilerek akvaryum balıklarının beyinlerinde yapılan bir çalışmada, kromun dozuna bağlı olarak GSH-Rd enzim aktivite miktarlarında düşüşlerin olduğu bildirilmiştir (Lushchak vd., 2009). Ayrıca çeşitli dozlarda Dietilditiokarbamat (DDC) maddesine maruz bırakılan S. cerevisiae hücrelerinin GSH-Rd enzim aktivite miktarının doz miktarına bağlı olarak arttığı bildirilmiştir (Lushchak vd., 2005). Bulgularımızın Dietilditiokarbamat (DDC) maddesine maruz birakılan $S$. cerevisiae hücrelerinin yapıldığı bu çalışmanın sonuçları ile uyumlu olduğu görülmektedir.

Süperoksit Dismutaz (SOD) enzimi, molekül ağırlığ 17-85 k DA aralığında olan, süperoksit radikallerinin dismutasyonunu sağlayarak moleküler oksijen ve $\mathrm{H}_{2} \mathrm{O}_{2}{ }^{\prime}$ e katalize eden metalloenzimdir. SOD enzimi oksijeni metabolize eden tüm hücrelerde bulunur ve aerobik organizmaları süperoksitin zararlı etkisine karşı koruma ve oksijen toksisitesini önlemede etkin olduğu bildirilmiştir (Sheng vd., 2004). Kontrol grubunda zamana bağlı olarak SOD enzim aktivite miktarlarında artışlar $(\mathrm{p}<0.005)$ gözlenirken, diğer grupların tümünde zamana bağlı olarak enzim aktivite miktarlarında artmaların $(\mathrm{p}<0.005)$ olduğu tespit edilmiştir. Krom dozunun artışına bağlı olarak grupların SOD enzim aktivite miktarlarında artmalar $(\mathrm{p}<0.005)$, artan $\mathrm{C}$ vitamini dozuna karşıllk SOD enzim aktivite miktarlarında ise azalmaların $(\mathrm{p}<0.005)$ olduğu belirlenmiştir (Şekil 7). İyonize radyasyon uygulanmış $S$. cerevisiae hücrelerinde SOD enziminin koruyucu etkileri araştırılmıştır. İyonize radyasyon uygulanmış yabani tip ve SOD geni delesyonlu suşlar arasında karşılaştırmalar yapılmış ve canlılık oranları ile protein karbonil düzeyleri arasında belirgin farklılıklar gözlenmiştir (Lee vd., 2001). S. cerevisiae' da CuZn-SOD enzimi eksikliğinin replikasyon ömrünün kısalmasına yol açttğ̆ ve mayaya askorbat eklenmesiyle mayanın replikasyon ömrünün $\operatorname{arttığ~} 1$ bildirilmiştir. Askorbatın bu görevi $\mathrm{CuZn-SOD}$ enzim aktivite miktarını arttırarak gerçekleştirdiği rapor edilmiştir (Wawryn vd., 1999; Swiecilo vd., 2000; Wawryn vd., 2002). Ayrica S. cerevisiae hücreleri hiperosmotik basinca ve $0.2 \mathrm{mM} \mathrm{H}_{2} \mathrm{O}_{2}$ dozuna maruz bırakılmış, her iki koşulda da SOD enzimi aktivite miktarlarının kontrol grubuna göre arttığ1 bildirilmiştir (Lu vd., 2005). Yine $\mathrm{Mn}, \mathrm{Cd}, \mathrm{Fe}$ ve $\mathrm{Mg}$ metallerinin $S$. cerevisiae mayasındaki antioksidan enzim aktiviteleri üzerine etkileri incelenmiş ve kontrol grubu ile bu metalleri içeren grupların SOD enzim aktivite miktarları karşılaştırılmıştır. Çalışma sonucunda bu metalleri ihtiva eden grupların SOD enzim aktivite miktarlarında artışların olduğu ve özellikle Cd ile muamele edilen gruplarda bu artışların daha fazla olduğu bildirilmiştir (Kireçci, 2018). Bulgularımızın belirtilmiş olan literatürlerle uyumlu olduğu görülmüştür.

Çalışmamızda memeli hücreleri gibi ökaryotik bir canlı olan S. cerevisiae' da kromun yol açtığı oksidatif strese karşı antioksidan cevap ile bu cevaba antioksidan özelliği bilinen $\mathrm{C}$ vitamininin etkisi araştırılmıştır. Sonuçta; kromun artan dozuna karşı maya örneklerinin hücre sayıları ile total protein miktarları azalırken, GSH-Px, GSH-Rd ve SOD enzim aktivite miktarlarında ise artışlar gözlenmiştir. Bu çalışma sonucunda kromun $S$. cerevisiae' da oksidatif strese yol açtı̆̆ metabolizmasını değişikliğe uğrattığı ve ortama ilave edilen $C$ vitamininin ise etkin bir süpürücü ve koruyucu olarak görev yaptığı tespit edilmiştir. 
Ökaryotik bir canlı olan S. cerevisiae ile yapılan bu tarz çalışmaların; memeli hücrelerindeki redoks dengelerinin aydınlatılması ve literatür bilgisine katkılar sağlanması açısından faydalı olabileceği kanaatine varılmıştır.

\section{Teşekkür}

Fırat Üniversitesi, Bilimsel Araştırma Projeleri birimi (FÜBAP) tarafindan FF 11.01 numaralı proje ile maddi olarak desteklenmiştir.

\section{Kaynaklar}

Bailey, J.E. and Ollis, D.F. (1986). Biochemical engineering fundamentals. 2nd Edition, Mc Graw Hill. Singapore.

Barnett, J.A. (1992). The taxonomy of the genus Saccharomyces Meyen ex Reess: A short review for nontaxonomists. Yeast, 81, 1-23.

Barnett, J.A., Payne, R.W. and Yarrow, D. (2000). Yeasts: characteristics and 1dentification, 3th Ed., Cambridge University Press, Cambridge p. 1139.

Beutler, E. (1984). Red cell metabolism. A manual of biochemical methods. 3th Ed. Grune \& Stratton Orlando.72-73, 7475, 105-106. ed, USA.

Blanguet, S., Marul-Bonnin, S., Beyssac, E., Pompon, D., Renaud, M. and Alric M. (2001). The 'biodrug' concept: on innovative approach to therapy. Trends in Biotechnology, 19 (10), 393400.

Boekhout, T., Robert, V. and Phaff, H., (2003). Yeast in food: beneficial and detrimental aspects. CRC Pres: Boca Raton,69-121.

Cabiscol, E., Piulats, E., Echave, P., Herrero, E. and Ros, J. (2000). Oxidative stress promotes specific protein damage in Saccharomyces cerevisiae. Journal of Biological Chemistry, 275 (35), 27393-27398.

Costa, V. and Moradas-Ferreira, P. (2001). Oxidative stress and signal transduction in Saccharomyces cerevisiae: insights into ageing, apoptosis and diseases. Molecular Aspects of Medicine, 22, 217-246.

Croce, C.D., Bronzettı, G., Cinı, M., Caltavuturo, L. and Po1, G. (2003). Protective effect of lipoic acid against hydrogen peroxide in yeast cells. Toxicology in Vitro, 17, 753- 759.

Çabuk, A., Akar, T., Kotluk, Z. ve Şaşmaz, S. (2007). Saccharomyces cerevisiae hücreleri ile ağır metal giderimi ve metal toleransı. Orlab On-Line Microbiyoloji Dergisi, 05-3:1-7.
Davies, M.J., Fu, S., Wang, H. and Dean, R.T. (1999). Stable markers of oxidant damage to proteins and their application in the study of human disease. Free Radical Biology and Medicine, 27(11-12), 1151-1163.

Droge, W. (2003). Oxidative stress and aging. Advances in Experimental Medicine and Biology, 543, 191-200.

Gokce, Z. (2020). The protective effect of pistacia vera L. (Pistachio) against to carbon tetrachloride (CCl4)-induced damage in saccharomyces cerevisiae. Progress in Nutrition, 22, 4. https://doi.org/ 10.23751/pn.v22i4.9901

Hamad, İ. (2007). Oksidatif stres uygulanmış Schizosaccharomyces pombe'de protein oksidasyonuna karşı doğal antioksidanların koruyucu etkisi. Doktora Tezi, İstanbul Üniversitesi Fen Bilimleri Enstitüsü, İstanbul.

Heves, M.D. (2008). Akyıldı (Ornithogalum sigmoideum Freyn Et Sint.)'ın antioksidan aktivitesi. Yüksek Lisans Tezi, İstanbul Üniversitesi Fen Bilimleri Enstitüsü, İstanbul.

Hierro, N., Gonzalez, A., Mas, A. and Guillamon, J.M. (2004). New PCR based methods for yeast identification. Journal of Applied Microbiology, 97, 792-801. https://doi.org/10.1111/j.13652672.2004.02369. $\mathrm{x}$

Jakobsen, M. and Norvhus, J. (1996). Yeast and their possible beneficial and p. negative effects on the quality of dairy products. International Dairy Journal, 6, 755-768.

Jakubowsk1, W. and Bartosz, G. (2000). 2,7Dichlorofluorescin oxidation and reactive oxygen species: what does it measure?. Cell Biology International, 24 (10): 757-760. https://doi.org/10.1006 / cbir.2000.0556.

Jianlong, W., Zeyu, M. and Xuan, Z. (2004). Response of Saccharomyces cerevisiae to chromium stres. Process Biochemistry, 39, 1231-1235.

Kahvecioğlu, Ö., Kartal, G., Güven, A. ve Timur, S. (2004). Metallerin çevresel etkileri I-II, İTÜ Metalurji ve Malzeme Mühendisliği Bölümü (Seminer çalışması 24s).

Kireçci, O.A. (2018). Mn, Cd, Fe ve Mg metallerinin Saccharomyces cerevisiae mayasında antioksidan enzim aktiviteleri üzerine etkisi. KSÜ Tarım ve Doğa Dergisi, 21(4), 520-528. https://doi.org/10.18016/ksudobil.359165

Korhan, H., Halipçi, H.N., Kertmen, M. ve Dı̆̆rak, M. (2012). Saccharomyces cerevisiae biyokütlesi ile remazol navy blue boyar maddesinin 
biyosorpsiyonu. KSÜ Doğa Bilimleri Dergisi, 15 (3).

Lee, J.H., Cho1, I.Y., K1l, I.S., K1m, S.Y., Yang, E.S. and Park, J.W. (2001). Protective role of superoxide dismutases against ionizing radiation in yeast. Biochimica et Biophysica Acta, 1526, 191-198. https://doi.org/ 10.1016/s0304-4165 (01) 00126$\mathrm{x}$

Lowry, O.H., Rosebrough, N.J., Farr, A.L. and Rondall, R.J. (1951). Protein measurement with the folin phenol reagent. Journal of Biological Chemistry, 193 (1), 265-275.

Lu, F., Wang, Y., Bai, D. and Du, L. (2005). Adaptive response of Saccharomyces cerevisiae to hyperosmotic andoxidative stres, Process Biochemistry, 40, 3614-3618. https://doi.org/ 10.1016 / j.procbio.2005.03.061

Lushchak, V., Semchyshyn, H., Lushchak, O. and Mandryk, S. (2005). Diethyldithiocarbamate inhibits in vivo $\mathrm{Cu}, \mathrm{Zn}$ superoxide dismutase and perturbs free radical processes in the yeast Saccharomyces cerevisiae cells. Biochemical and Biophysical Research Communications, 338 (4), 1739-1744. https://doi.org/ 10.1016/ j.bbrc.2005.10.147

Lushchak, O.V., Kubrak, O.L., Torous, I.M., Nazarchuk, T.Y., Storey, K.B. and Lushchak, V.I. (2009). Trivalent chromium induces oxidative stress in goldfish brain. Chemosphere, $75 \quad$ (1), 56-62. https://doi.org/10.1016/j.chemosphere.2008.11. 052

Mandavillı, B.S., Santos, J.H. and Van Houten, B. (2002). Mitochondrial DNA repair and aging, Mutation Research, 509 (1-2), 127-151. https://doi.org/10.1016/s0027-5107(02)00220-8

Öcal, E. (2008). Saccharomyces cerevisiae 4 ve Saccharomyces cerevisiae 2S1 TP (3-2) suşlarının ağır metal dirençlilikleri ve hücresel total protein miktarlarının araştırılması. Yüksek Lisans Tezi, Gazi Üniversitesi, Fen Bilimleri Enstitüsü, Ankara.

Öztürk, H. (2003). In-vitro-studien zum Einfluss von topinamburmehl und Saccharomyces boulardii auf den mikrobiellen vormagenstoffwechsel. Diss, Tierarztliche Hochschule Hannover, Germany, 91.

Paglia D.E. and Valetine, W.N. (1967). Studies on the quantitative and qualitative characterization of erytrocyte glutathione peroxidase. Journal of Laboratory and Clinical Medicine, 70,158-169.

Parapouli, M., Vasileiadis, A., Afendra, A.S. and Hatziloukas, E. (2020). Saccharomyces cerevisiae and its industrial applications. AIMS
Microbiology, 6 (1), 1-31. https://doi.org/ 10.3934/microbiol.2020001

Patring, J.D., Jastrebova, J.A., Hjortmo, S.B., Andlid, T.A. and Jägerstad, I.M. (2005). Development of a simplified method for the determination of folates in baker's yeast by HPLC with ultraviolet and fluorescence detection. Journal of Agricultural Food Chemistry, 53, 2406-2411.

Pekmez, M., (2004). Oksidatif stres uygulanmış Schizosaccharomyces pombe'de moleküler çalışmalar, Yüksek Lisans Tezi, İstanbul Üniversitesi Fen Bilimleri Enstitüsü, İstanbul.

Piotrowska, A., Mlyni, K., Siwek, A., Dybala, M., Opoka, W., Poleszak, E. and Nowak, G. (2008). Antidepressant like effect of chromium chloride in the mouse forced swim test: involvement of glutamatergic and serotonergic receptors. Pharmacological Reports, 60 (6), 991-995.

Saegusa, S., Totsuka, M., Kaminogawa, S. and Hasai, T. (2004). Candida albicans and Saccharomyces cerevisiae induce interleukin-8 production from intestinal epithelial- like caco-2 cells in the presence of butyric acid. FEMS Immunology and Medical Microbiology, 41, 227-235.

Sheng, L., Zheng, X., Tong, H., Liu, S., Du, J. and Liu, Q. (2004). Purification and characterization of cytosolic 1soenzyme III of $\mathrm{Cu}, \mathrm{Zn}$ - Superoxide dismutase from tobacco leaves. Plant Science, 167 (6), 1235-1241.

Sun, Y., Oberley, L.W. and L1, Y. (1988). A simple method for clinical assay of Superoxide Dismutase. Clinical Chemistry, 34(3), 497-500.

Swiecilo, A., Krawiec, Z., Wawryn, J., Bartosz, G. and Bilinski, T. (2000). Effect of stress on the life span of the yeast Saccharomyces cerevisiae. Acta Biochimica Polonica, 47 (2), 355-364.

Szaleczky, E., Prechl, J., Fehér, J. and Somogyi, A. (1999). Alterations in enzymatic antioxidant defence in diabetes mellitus-a rational approach. Postgraduate Medical Journal, 75 (879), 13-17. https://doi.org/10.1136/pgmj.75.879.13

Walker, G.M. (1998). Yeast Physiology and Biotechnology, John Wiley \& Sons, England, 0471-964468.

Walker, G.M. (2000). Yeast physiology and biotechnology, Wiley and Sons, England.

Wawryn, J., Krzepilko, A., Myszka, A. and Bilinski, T. (1999). Deficiency in superoxide dismutases shortens life span of yeast cells. Acta Biochimica Polonica, 46 (2), 249-353.

Wawryn, J., Swiecilo, A., Bartosz, G. and Bilinski, T. (2002). Effect of superoxide dismutases 
deficiency on the life span of the yeast Saccharomyces cerevisiae. An oxygenindependent role of $\mathrm{Cu}, \mathrm{Zn}$ superoxide dismutase. Biochimica et Biophysica Acta, 1570 (3), 199-202. https://doi.org/10.1016/s03044165(02)00197-6

Yağmur, G. (2006). Mitokondriyal mutantların bira fermantasyonu üzerine etkisi. Yüksek Lisans Tezi, Çukurova Üniversitesi Fen Bilimleri Enstitüsü, Gıda Mühendisliği Anabilim Dalı, Adana.

Yang, L. and Chen, J.P. (2007). Biosorption of hexavalent chromium onto raw and chemically modified Sargassum sp. Bioresource $\begin{array}{llll}\text { Technology, } & 99 & \text { (2), } & \text { 297-307. }\end{array}$ https://doi.org/10.1016 / j.biortech.2006.12.021

Zouboulis, A.I. and Katsoyiannis, I.A. (2004). Recent advances for the bioremediation of arsenic from contaminated groundwater sources. In: 6th Intern. Conf. On "Metallurgy, Refractories and Environment" (invited lecture), organized by T.U. Kosice (Slovakia) and Slovak Metallurgical Society in High Tatras (Slovakia), Proceedings published by the Organizers (E. Vircikova, ed.), 267-274. 